\title{
Third Report of the Cooperative, Open-Ended Study of Slowly Growing Mycobacteria by the International Working Group on Mycobacterial Taxonomy
}

\author{
L. G. WAYNE, ${ }^{1 *}$ R. C. GOOD ${ }^{2}$ M. I. KRICHEVSKY,${ }^{3}$ Z. BLACKLOCK,${ }^{4}$ H. L. DAVID, ${ }^{5}$ D. DAWSON ${ }^{4}$ \\ W. GROSS,${ }^{6}{ }^{\text {J. HAWKINS }}{ }^{6}$ P. A. JENKINS ${ }^{7}$ I. JUHLIN,${ }^{8}$ W. KÄPPLER,${ }^{9}$ H. H. KLEEBERG, ${ }^{10}$ \\ V. LEVY-FREBAULT,${ }^{5}$ C. MCDURMONT ${ }^{11}$ E. E. NEL,${ }^{10}$ F. PORTAELS, ${ }^{12}$ S. RÜSCH-GERDES, ${ }^{13}$ \\ K. H. SCHRÖDER, ${ }^{13}$ V. A. SILCOX ${ }^{2}$ I. SZABO,${ }^{14}$ M. TSUKAMURA,${ }^{15}$ L. VAN DEN BREEN, ${ }^{12}$ \\ B. VERGMANN ${ }^{16}$ AND M. A. YAKRUS ${ }^{2}$ \\ Veterans Administration Medical Center, Long Beach, California $90822^{1}$; Centers for Disease Control, Atlanta, Georgia \\ $30333^{2}$; National Institute of Dental Research, Bethesda, Maryland 202053 ; State Health Laboratory, Brisbane, \\ Australia ${ }^{4}$; Institut Pasteur, Paris, France ; Veterans Administration Medical Center, West Haven, Connecticut 06516 ${ }^{6}$; \\ University Hospital of Wales, Cardiff, Wales ${ }^{7}$; Institute of Clinical Bacteriology, Malmö, Sweden ${ }^{8}$; Forschunginstitut fur \\ Lungenkrankheiten und Tuberkulose, Berlin-Buch, German Democratic Republic ${ }^{9}$; Tuberculosis Research Institute, South \\ African Medical Research Council, Pretoria, South Africa ${ }^{10}$; State Department of Public Health, Montgomery, Alabama \\ $36130^{11}$; Institute of Tropical Medicine, Antwerp, Belgium ${ }^{12}$; Tuberkulose Forschungsinstitut, Borstel, Federal Republic of \\ Germany $^{13}$; Koranyi National Institute of Tuberculosis and Pulmonology, Budapest, Hungary ${ }^{14}$; Chubu Chest Hospital, \\ Obu, Aichi-Ken, Japan ${ }^{15}$; and Statens Seruminstitut, Copenhagen, Denmark ${ }^{16}$

\begin{abstract}
The open-ended study of the International Working Group on Mycobacterial Taxonomy is an ongoing project designed to characterize slowly growing strains of mycobacteria that do not belong to well-established or thoroughly characterized species. In this third report we describe numerical clusters that encompass the type strains of Mycobacterium szulgai, Mycobacterium triviale, Mycobacterium shimoidei, Mycobacterium asiaticum, Mycobacterium simiae, and Mycobacterium malmoense. Descriptions and discussion of the taxonomic status of three additional unnamed clusters, as well as a cluster that encompasses the erstwhile type strain of the presently invalid species "Mycobacterium paraffinicum," are also presented.
\end{abstract}

The first cooperative studies of the International Working Group on Mycobacterial Taxonomy (IWGMT) applied numerical taxonomic (NT) analysis to the circumscription of clusters and description of strains that corresponded to established species of mycobacteria $(7,12,16,19,29,34)$. The data were generated under permissive rules; i.e., participants chose the tests and methods which they used without restrictions by the study coordinators. Separate studies were later undertaken to evaluate the reproducibility of tests that defined the most powerful differential features; the methods used in these reproducibility studies were described and adhered to precisely $(35,36)$.

In 1977 , a cooperative open-ended study was initiated under permissive rules of test selection, in which new strains of slowly growing mycobacteria were introduced on a continuing basis, and the data were analyzed at intervals. The purpose of this study of an expanding set of strains was to characterize slowly growing mycobacterial strains that represented uncommonly encountered species that had not been represented in the first six studies, as well as to recognize clusters of previously unknown taxa.

In the first published report of the open-ended study (37), some "old data" from unclustered strains and from selected type and marker strains in previously published IWGMT studies $(16,29,34)$ were combined with "new data" from the strains that had been distributed for the open-ended study. Because of differences in types and numbers of features in the two series of studies, merging the two data bases led to perturbation of the NT matrices (37). In the second report of the open-ended study (38), one analysis was based solely on new data; this excluded a number of type strains of reference

\footnotetext{
* Corresponding author.
}

species. Most of these strains have now been recoded and were distributed for the generation of new data in the current study. These data, as well as data for newly acquired strains, are included in this third report.

In this report, we include descriptions of expanded $M y c o-$ bacterium asiaticum and "Mycobacterium paraffinicum" clusters, which were recognized tentatively in the second report (38), and four clusters that were not recognized in prior reports of this study, as well as expanded descriptions of four previously described clusters that correspond to Mycobacterium szulgai, Mycobacterium shimoidei, Mycobacterium simiae, and Mycobacterium malmoense $(37,38)$.

\section{MATERIALS AND METHODS}

Selection of strains. The criteria for and mechanics of introducing cultures into this study have been described previously (37). For reasons discussed previously (38), this report is based on data derived solely from strains that were distributed, freeze-dried, specifically for this open-ended study.

Editing and analysis of data. In addition to the criteria discussed previously $(26,37,38)$, two more criteria for suppression of data were introduced into the current analysis. Antimicrobial agents were often tested over wide ranges of concentrations in participating laboratories. The number of concentrations actually entered into the analysis was restricted to no more than three for any drug; the selection was based in part on concentrations that were used by the greatest number of investigators. In addition, the editing program automatically suppressed any feature that was missing for more than $20 \%$ of the test strains in performing the NT analysis. NT analyses were based on simple matching coefficients, with sorting by unweighted average linkage 
$(23,26)$, and a table of feature frequencies was generated for selected clusters (27). The result ascribed to a given strain in a given test, both for NT analyses and for tabulations of feature frequencies, was the modal score (i.e., the result obtained for that strain by the majority of laboratories that performed that test) (39).

\section{RESULTS}

After suppression of redundant and incomplete data according to the criteria specified above, an NT analysis based on the 146 remaining features was conducted for 172 strains. The complete matrix (Fig. 1) was resolved into four subsets for convenience of visualization and interpretation (Fig. 2 to 5). After clusters were defined, mean intra- and intercluster matching scores (Table 1) and mean matching scores for each cluster compared with each of the type strains (Table 2) were calculated. Feature frequencies were tabulated for 45 properties that provided the best resolution among 10 clusters (Table 3). The frequency of any feature for a given cluster is shown in Table 3 only if data were available from five or more strains. Feature distributions in clusters 4 (Mycobacterium gordonae), 7 (Mycobacterium intracellulare), 8 (Mycobacterium scrofulaceum), and 11 (Mycobacterium avium) were not tabulated because these species had been characterized in previous IWGMT studies that were not open ended $(16,34)$. The criteria for entering a strain into the present study were meant to exclude well-defined members of these species, and strains that escaped the exclusion criteria were likely to be atypical of the species in some key properties.

The first NT subset (Fig. 2) includes cultures derived from the type strains of Mycobacterium flavescens (strain OES 90117, from strain TMC 1541 [= ATCC $14474^{\mathrm{T}}$ ]), $M$. szulgai (strain OES 90134, from strain TMC $1328[=$ NCTC $10831^{\mathrm{T}}$ ]), Mycobacterium kansasii (strain OES 90130, from strain TMC 1204 [= ATCC $12478^{\mathrm{T}}$ ]), Mycobacterium xenopi (strain OES 90137, from strain TMC $1482[=$ NCTC $\left.10042^{\mathrm{T}}\right]$ ), Mycobacterium gastri (strain OES 90136, from strain TMC $1456\left[=\right.$ ATCC $\left.\left.15754^{\mathrm{T}}\right]\right)$, the "terrae complex" (i.e., Mycobacterium terrae (strain OES 90120, from strain TMC 1450 [= ATCC $\left.15755^{\mathrm{T}}\right]$ ), Mycobacterium nonchromogenicum (strain OES 90118, from strain TMC 1481 [= ATCC $\left.19530^{\mathrm{T}}\right]$ ), and Mycobacterium triviale (strain OES 90119, from strain TMC 1453 [ = ATCC $\left.23292^{\mathrm{T}}\right]$ ), as well as M. shimoidei (strain OES 90013, from strain Tsukamura 4796 [ = ATCC $\left.\left.27962^{\mathrm{T}}\right]\right)$.

Cluster 1 (Fig. 2) consists of seven strains with a mean internal matching score (MIMS) of $86.0 \%$ and a mean matching score of $74.2 \%$ or less with all other clusters (Table 1). It includes the type strain of $M$. szulgai (14), with which it exhibited a mean matching score of $84.9 \%$; the next highest score was $79.6 \%$, with the type strain of $M$. kansasii (Table 2). The M-catalases from five of these strains (strains OES 90001, OES 90011, OES 90020, OES 90036, and OES 90046) all gave reactions of identity as determined by seroprecipitation against cross-absorbed antibody to $\mathrm{M}$-catalase from the type strain of $M$. szulgai (32). This cluster has been discussed previously (38).

A previous non-open-ended study of the IWGMT included clusters representing $M$. nonchromogenicum and $M$. terrae (16), so only the type strains were used in the present study as markers for these species. Strains of $M$. triviale were not included in the prior study, so strains considered to belong to this species were included in the present study and were members of cluster 2 (Fig. 2). This cluster exhibited a MIMS of $86.8 \%$ and a mean matching score of $74.7 \%$ or less with all other clusters (Table 1). It includes the type strain of $M$. triviale (13), with which it had a mean matching score of $83.6 \%$, but the mean matching scores with the type strains of $M$. terrae and $M$. nonchromogenicum were only 78.3 and $74.8 \%$, respectively (Table 2 ). Strains of $M$. triviale differ from representatives of the other two species in the terrae complex by their ability to grow in the presence of $5 \%$ sodium chloride (Table 3) (13). These cultures exhibited spontaneous agglutination and could not be serotyped. None was submitted as a significant pathogen.

Cluster 3 (Fig. 2) consists of six strains with a MIMS of $86.5 \%$ and a mean matching score of $77.7 \%$ or less with all other clusters (Table 1). The MIMS is probably distorted by the fact that three of the cultures (strains OES $90013^{\mathrm{T}}[\mathrm{T}=$ type strain], OES 90014, and OES 90015) were derived from the same patient. Strain OES $90013^{\mathrm{T}}$ is the type strain of $M$. shimoidei (24); cluster 3 exhibited a mean matching score of $86.9 \%$ with this strain and scores of $79.5 \%$ or less with all other type strains examined in this study. All cultures exhibited spontaneous agglutination and could not be serotyped. Several features distinguish members of this cluster from other clusters (Table 3). The type strain was isolated from a patient in Japan and was considered to be the agent of pulmonary disease. Two of the strains in this cluster were isolated in Australia; one was considered to be the cause of disease. One strain of unknown significance was isolated in Mississippi.

The second subset (Fig. 3) contains three clusters and includes cultures derived from the type strains of two species, $M$. gordonae (strain OES 90133, from strain TMC 1324 [ = ATCC $14470^{\mathrm{T}}$ ) and $M$. asiaticum (strain OES 90126, from strain TMC 803 [= ATCC 25276 $\left.{ }^{\mathrm{T}}\right]$ ). Cluster 4 (Fig. 3) consists of 10 strains with a MIMS of $85.3 \%$ and mean matching scores of $78.2 \%$ or less with all other clusters (Table 1). It includes the type strain of $M$. gordonae, with a mean matching score with this strain of $85.7 \%$ (Table 2). $M$. gordonae was examined in previous studies, so most of these strains escaped the exclusion criteria by exhibiting unusual responses in key characters that were used for screening; e.g., $30 \%$ of the members of cluster 4 were nonpigmented, $60 \%$ were urease positive, and only $50 \%$ yielded more than $45 \mathrm{~mm}$ of foam in the semiquantitative catalase test, compared with expected frequencies of $<1$, $<1$, and $92 \%$, respectively (39).

Cluster 5 (Fig. 3) consists of 11 strains with an MIMS of $84.8 \%$ and mean matching scores of $78.8 \%$ or less with all other clusters (Table 1). This cluster includes the type strain of $M$. asiaticum (41), with a mean matching score with this strain of $83.5 \%$ (Table 2). Cluster 5 is well separated from cluster 4 , with a mean intercluster matching score of only $77.3 \%$; the mean matching score of cluster 5 compared with the type strain of $M$. gordonae is only $77.2 \%$. However, this apparent distinction is influenced in part by the atypical nature of the strains in cluster 4 and is accentuated by several moderately variable features of strains in cluster 5 , which are not sufficiently consistent to be useful for diagnostic purposes. The most striking feature for distinguishing between members of the two species is the consistent photochromogenic behavior of $M$. asiaticum (Table 3). The M-catalases from three of these strains (strains OES 90028, OES 90052, and OES 90053) were tested by seroprecipitation against cross-absorbed antibody to M-catalase from the type strain of $M$. asiaticum, and all gave reactions of identity (32); none gave significant cross-reactions with the $M$. gordonae reference system. Although most of the strains were 


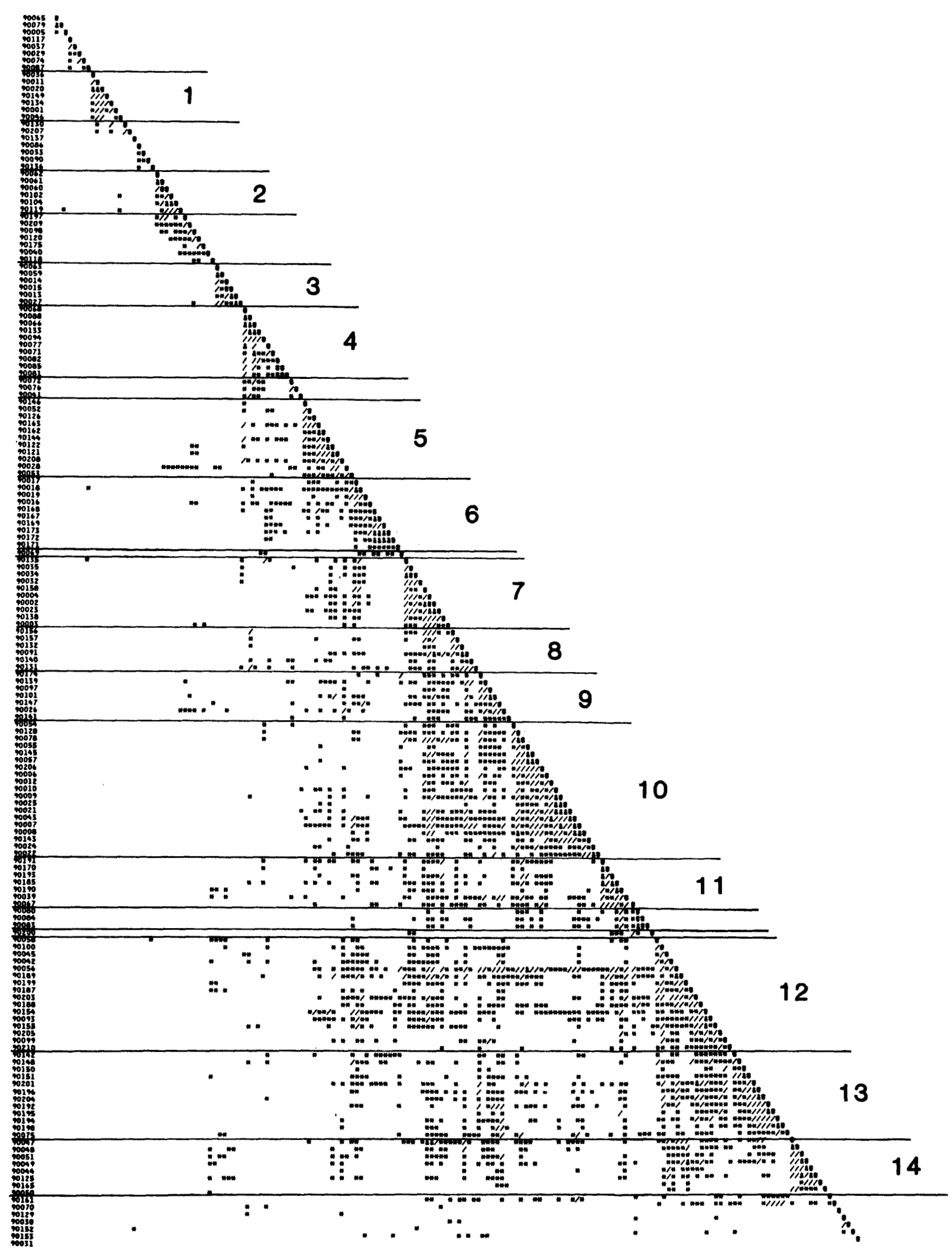

FIG. 1. NT matrix of 172 strains of slowly growing mycobacteria, based on 146 features. Symbols are defined on Fig. 2 . Symbols that represent matching scores below $80 \%$ were not included to help visualize clusters. 


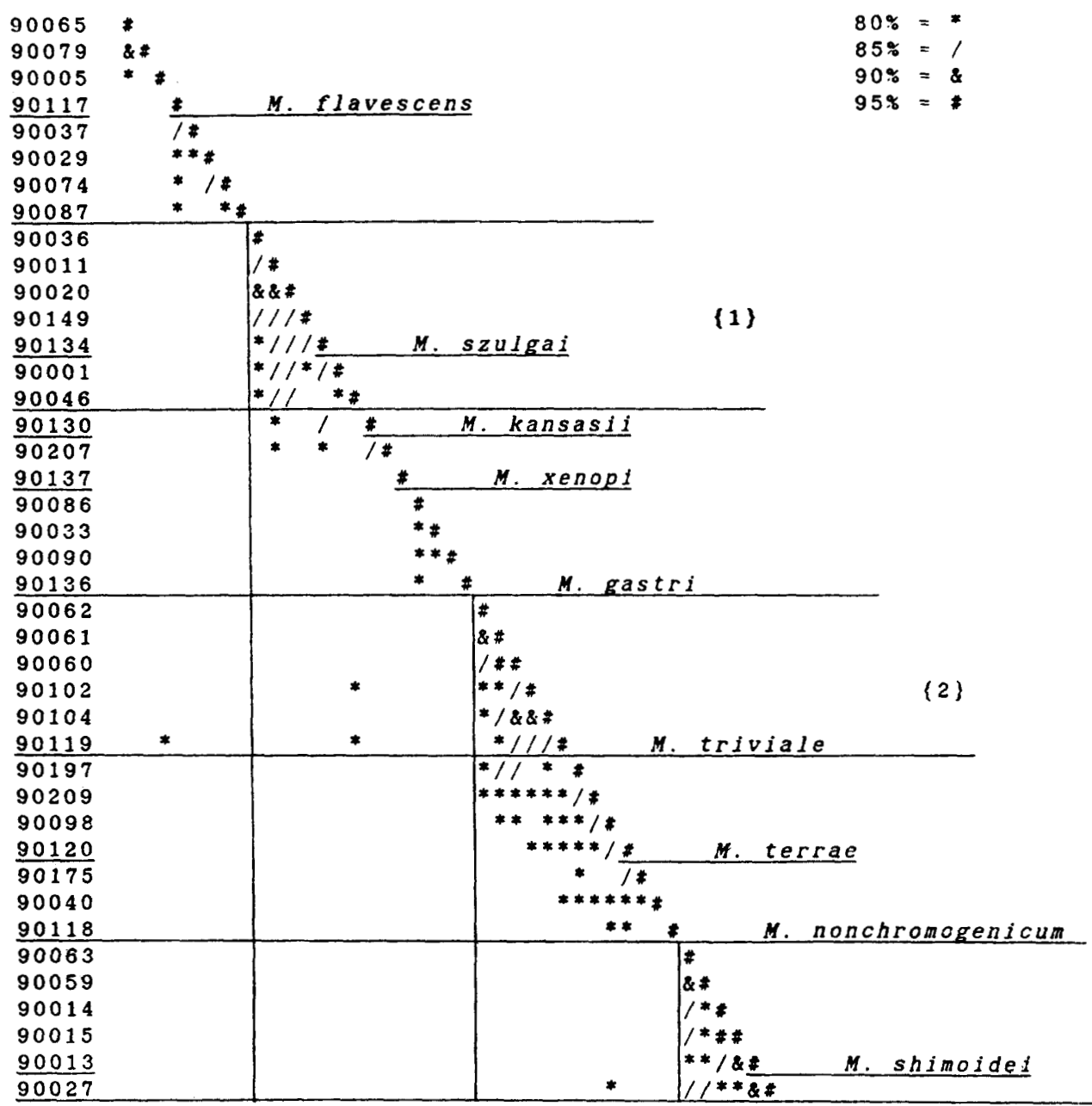

FIG. 2. NT subset matrix of 41 strains of slowly growing mycobacteria. Names indicate that the culture examined was derived from the type strain. See also the legend to Fig. 1.

smooth, oniy one of four laboratories performing seroagglutination studies was able to identify one strain (OES 90122) as of serovar "asiaticum." None of the other strains could be assigned to a serovar. Strain OES 90146 was derived directly from strain ATCC $25276^{\mathrm{T}}$, and strain OES 90126 was derived from strain TMC $803\left(=\right.$ ATCC $\left.25276^{\mathrm{T}}\right)$. Thus, both of these strains were derived from the type strain, which was isolated in Hungary from a monkey from India, as was strain OES 90144. One strain was found in the lymph node of a pig. Two of the strains were isolated from human sputum and were considered clinically significant, two more strains were isolated on more than one occasion from patients with chronic bronchitis and were considered possible secondary invaders, and three strains were considered insignificant. One nonsignificant human isolate was from the United States, and the balance of the cultures were from Australia.

Cluster 6 (Fig. 3) consists of 10 cultures with a MIMS of $84.9 \%$ and mean matching scores of 78.8 and $78.6 \%$ with clusters 5 and 12, respectively; the mean matching scores with all other clusters were less than $78.6 \%$ (Table 1). Cluster 6 contained none of the type strains and exhibited its highest mean matching score $(78.6 \%)$ with strain OES 90135 , which was derived from the type strain of $M$. intracellulare (Table 2). Members of cluster 6 were most consistently distinguished from members of cluster 5 by their suscepti- bility to $16 \mu \mathrm{g}$ of cycloserine per $\mathrm{ml}$, their resistance to $32 \mu \mathrm{g}$ of rifampin per ml, their lack of pigment, and their positive responses to tests for nicotinamidase and pyrazinamidase (Table 3). Most of the members of cluster 6 were distinguished from $M$. avium and $M$. intracellulare by their high catalase activity and their ability to hydrolyze Tween 80 (Table 3) (39). Four cultures (strains OES 90016, OES 90017, OES 90018, and OES 90019) were derived from the same patient in Japan (25); they could not be typed by any of the laboratories performing seroagglutination tests. The remaining six cultures were isolated from sputa of different patients over an 18-month period in a laboratory in Japan; only one was considered to be clinically significant. Five of these cultures were agglutinated by antibody to $M$. szulgai in one laboratory, but none yielded a confirmatory absorption test.

The third subset (Fig. 4) contains five clusters and includes cultures derived from the type strains of $M$. intracellulare (strain OES 90135, from strain TMC $1406[=$ ATCC $13950^{\mathrm{T}}$ ]), $M$. avium (strain OES 90138 , from strain TMC 724 [= ATCC 25291 ${ }^{\mathrm{T}}$ ), M. scrofulaceum (strain OES 90132, from strain TMC 1323 [= ATCC $\left.19981^{\mathrm{T}}\right]$ ), the presently invalid species " $M$. paraffinicum" (strain OES 90139, from strain ATCC 12670), and $M$. simiae (strain OES 90128, from strain TMC 1226 [= ATCC 25275' $]$ ). Cluster 7 (Fig. 4) consists of 10 strains with a MIMS of $86.4 \%$ and matching 


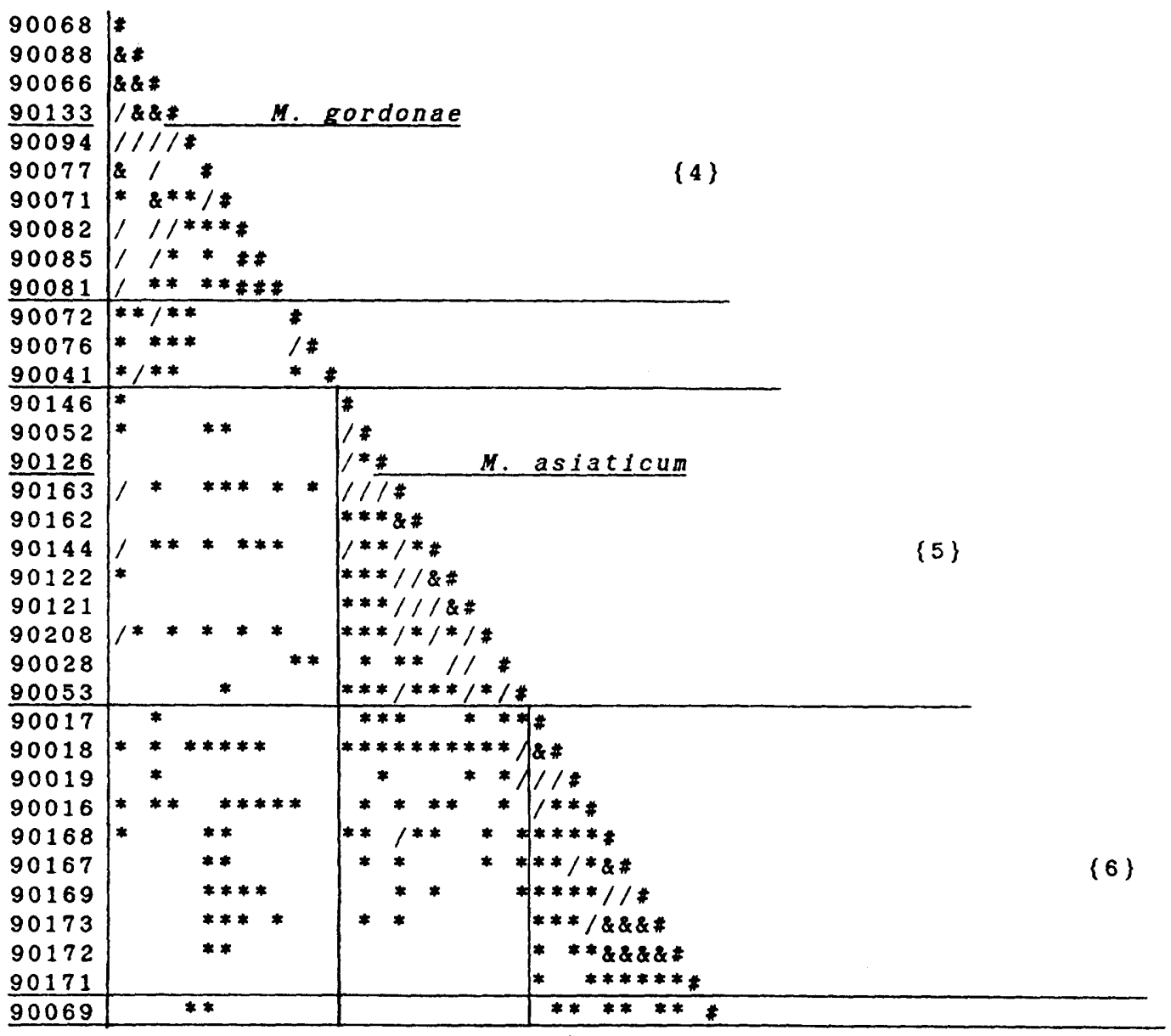

FIG. 3. NT subset matrix of 35 strains of slowly growing mycobacteria. See also the legends to Fig. 1 and 2.

scores of $80.8 \%$ with cluster $8,80.3 \%$ with cluster $9,79.9 \%$ with cluster 10 , and $79.6 \%$ with cluster 11 (Table 1). Cluster 7 includes the type strains of both $M$. intracellulare and $M$. avium (22), with mean matching scores of 87.7 and $85.4 \%$, respectively (Table 2). Five strains in this cluster appeared in the MAIS-1 cluster in a prior report (38) and were considered to be variants of $M$. intracellulare or $M$. avium, a conclusion that is supported by the results of the present analysis. Eight of the strains in cluster 7 belonged to agglutinating serovars that are usually restricted to $M$. intracellulare $(2,33)$; strain OES 90032 agglutinated as $M$. avium serovar 6 , and strain OES 90138, which was derived from the type strain of $M$. avium, agglutinated in one laboratory as serovar 2 and in another as serovar 16. After the code was broken, the participants from the West Haven Veterans Administration Medical Center examined type-derived strains OES 90135 and OES 90138 with specific nucleic acid probes (GenProbe, San Diego, Calif.) and confirmed them as $M$. intracellulare and $M$. avium, respectively.

Cluster 8 (Fig. 4) consists of six strains, with a MIMS of $85.0 \%$ and mean matching scores of $80.8 \%$ or less with all other clusters (Table 1). Cluster 8 includes the type strain of $M$. scrofulaceum (22), with a mean matching score of $86.7 \%$; it exhibits a mean matching score of $82.5 \%$ with the marker strain of " $M$. paraffinicum" in cluster 9 (Table 2). For reasons cited above, feature frequences for cluster 8 are omitted from Table 3.

Cluster 9 (Fig. 4) consists of seven strains, with a MIMS of $84.6 \%$, and mean matching scores of $80.3 \%$ with cluster 7 ,
$80.1 \%$ with cluster $8,80.2 \%$ with cluster 10 , and $80.8 \%$ with cluster 13 (Table 1). It includes marker strain OES 90139, with a mean matching score of $85.7 \%$ (Table 2); this culture was derived from what had been the type strain of " $M$. paraffinicum" (6) until that species lost standing by omission from the Approved Lists of Bacterial Names (22). Features that may be useful for differentiating strains in cluster 9 from $M$. scrofulaceum include growth at $42^{\circ} \mathrm{C}$ and urease production, with frequencies of 88 and $91 \%$, respectively, for $M$. scrofulaceum (39) and $<1 \%$ for members of cluster 9 (Table 3). Most members of cluster 9 may be differentiated from $M$. simiae (cluster 10) by the nature of their pigmentation and by their urease reactions (Table 3). Clusters 9 and 13 are poorly differentiated from one another by key biochemical tests, with Tween hydrolysis providing some resolution (Table 3). Cluster 9 included strains from Australia, Japan, and the United States. Only one strain (strain OES 90097) was considered clinically significant; it was isolated at the autopsy of a child whose sibling also had died of a disseminated mycobacterial infection, suggesting a hereditary immune defect.

Cluster 10 consisted of 19 strains with an MIMS of $84.8 \%$ and mean matching scores of $79.9 \%$ with cluster $7,80.0 \%$ with cluster 8 , and $80.2 \%$ with cluster 9 (Table 1). This cluster includes the type strain of $M$. simiae (11), with a mean matching score of $87.0 \%$; the next highest score was $82.1 \%$ with the marker strain of cluster 9 (Table 2). The M-catalases from 10 of the strains (strains OES 90006, OES 90007, OES 90008, OES 90010, OES 90012, OES 90021, 


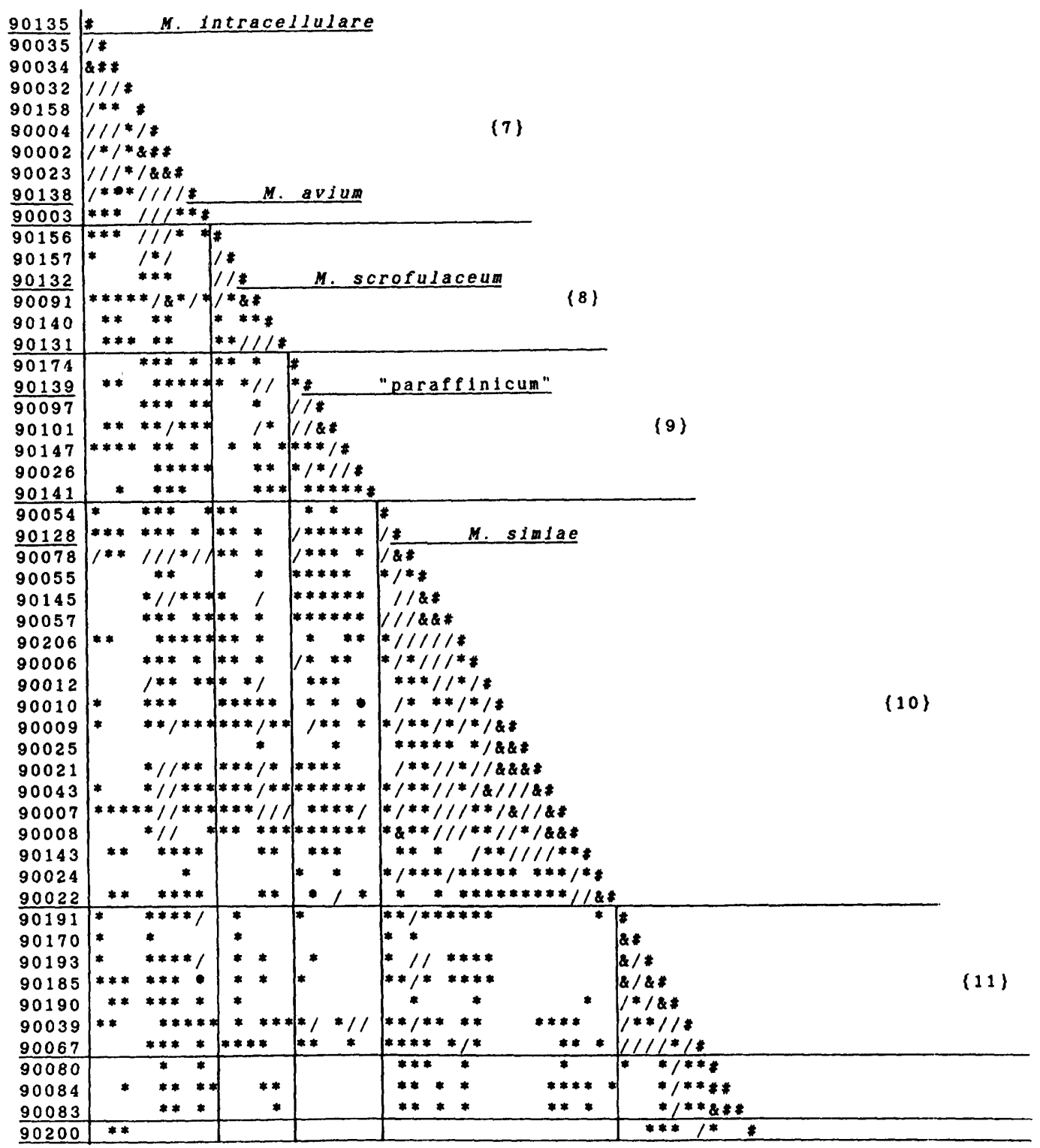

FIG. 4. NT subset matrix of 53 strains of slowly growing mycobacteria. See also the legends to Fig. 1 and 2.

OES 90022, OES 90024, OES 90025, and OES 90043) gave reactions of identity by seroprecipitation against crossabsorbed antibody to M-catalase from the type strain of $M$. simiae (32). This cluster was discussed in prior reports $(37$, 38); updated feature frequencies are included in Table 3.

Cluster 11 consists of seven strains with a MIMS of $87.7 \%$ and mean matching scores of $79.8 \%$ or less with all other clusters (Table 1). This cluster did not include any marker strains, but exhibited a mean matching score of $83.4 \%$ with the type strain of $M$. avium, which appeared in cluster 7 (Table 2). One of the strains exhibited spontaneous agglutination, and another was not tested, but the remaining five agglutinated as serovars that are considered to belong to $M$. avium $(2,33)$. After the code was broken, the participants from the West Haven Laboratory examined strains OES 90170, OES 90185, OES 90191, and OES 90193 with the nucleic acid probe and confirmed all four as members of $M$. avium.

The three cultures that follow cluster 11 (Fig. 4) (strains
OES 90080, OES 90083, and OES 90084) were determined to have been isolated from one patient and are not treated as a cluster of different strains.

The fourth subset (Fig. 5) contains three clusters and includes cultures derived from the type strains of $M$. malmoense (strain OES 90125, from strain TMC 802 [= ATCC $\left.29571^{\mathrm{T}}\right]$ ), and Mycobacterium marinum (strain OES 90129 , from strain TMC 1218 [= ATCC 927 $]$ ). Clusters 12 (16 strains with a MIMS of $83.4 \%$ ) and 13 (12 strains with a MIMS of $85.4 \%$ ) are poorly resolved from one another, with a mean matching score of $81.2 \%$ between them (Table 1 ). Cluster 12 exhibits mean matching scores of 81.1 and $80.6 \%$ with the type strains of $M$. avium and $M$. malmoense, respectively; cluster 13 exhibits mean matching scores of 79.5 and $78.0 \%$ with the type strains of $M$. simiae and $M$. malmoense, respectively (Table 2 ). The cultures in clusters 12 and 13 were predominantly from laboratories in the United States, with a few from Europe; many of the United States strains had been submitted with the comment that 


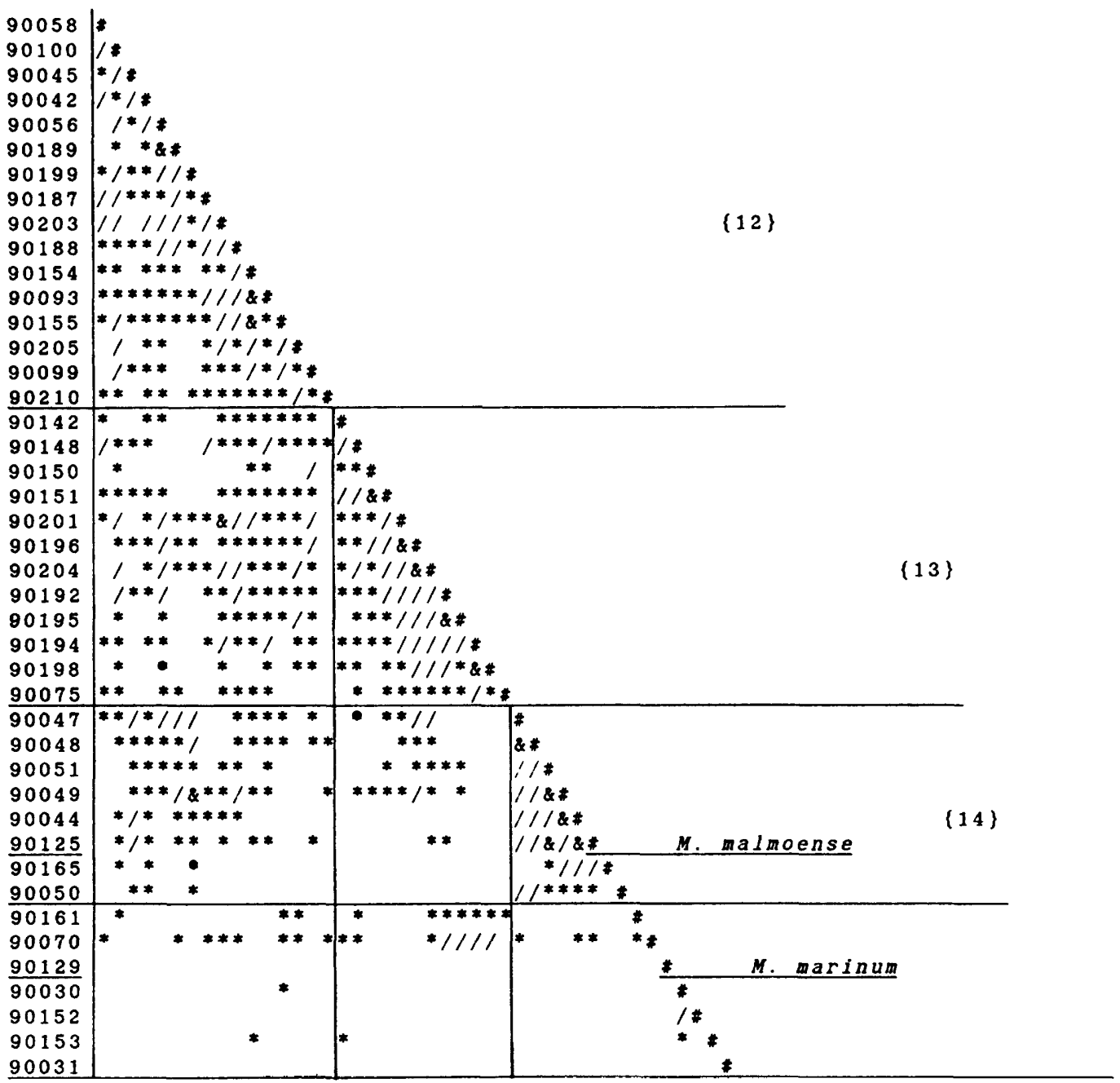

FIG. 5. NT subset matrix of 43 strains of slowly growing mycobacteria. See also the legends to Fig. 1 and 2.

they resembled $M$. malmoense. Six of the strains in cluster 12 and five of the strains in cluster 13 were considered to be clinically significant. Information on the significance of the rest of the strains in these two clusters was not available. The data in Table 3 (and from the entire untabulated data set) do not identify any single phenotypic feature or combination of features that permits strains to be assigned unequivocally to one or the other of these two clusters. Tests for Tween hydrolysis, pigmentation, growth at $42^{\circ} \mathrm{C}$, and urease, in combination, would be useful for excluding members of cluster 12 or 13 from $M$. avium or $M$. simiae (Table 3) (40). Tests for pigmentation, urease, and catalase would be helpful in distinguishing them from $M$. malmoense (Table 3). Workers in one laboratory found that strains OES 90045 and OES 90042 in cluster 12 are members of the agglutination serovar characteristic of $M$. malmoense; workers in another laboratory reported that strain OES 90045 exhibits a thinlayer chromatography (TLC) lipid pattern like that of $M$. malmoense, but did not report any result for strain OES 90042. No other laboratory in this study appears to have had a reference system for agglutination serotyping of $M$. malmoense, and the laboratory that did have this system did not submit any results for nine of the strains in cluster 12 . The serological and TLC results suggest that some strains in cluster 12 (Fig. 5) may actually belong in cluster 14 and that there may be another taxon buried in cluster 12 that has not been clearly defined by NT. No seroagglutination results for any of the strains in cluster 13 were submitted by the laboratory with the $M$. malmoense reference system, so a similar situation may exist in that cluster.

Cluster 14 (Fig. 5) consists of eight strains with a MIMS of $86.5 \%$ and mean matching scores of $79.9 \%$ or less with all other clusters (Table 1). The mean matching score of this cluster with the type strain of $M$. malmoense (21) was $87.8 \%$, and the mean matching score was $78.1 \%$ or less with all other marker strains in the study. Strains OES 90044, OES 90047 , OES 90048, and OES 90049 reacted like $M$. malmoense as determined by seroagglutination and by lipid TLC; strains OES 90050 and OES 90051 gave an $M$. malmoense TLC pattern, but failed to agglutinate with any reference sera; strain OES 90165 agglutinated as $M$. malmoense, but was not tested by TLC; enigmatically, the type strain of $M$. malmoense, strain OES 90125, agglutinated like $M$. avium serovar 28, and TLC was not performed. All strains in cluster 14 were clinically significant.

\section{DISCUSSION}

The Ad Hoc Committee on Reconciliation of Approaches to Bacterial Systematics of the International Committee on 


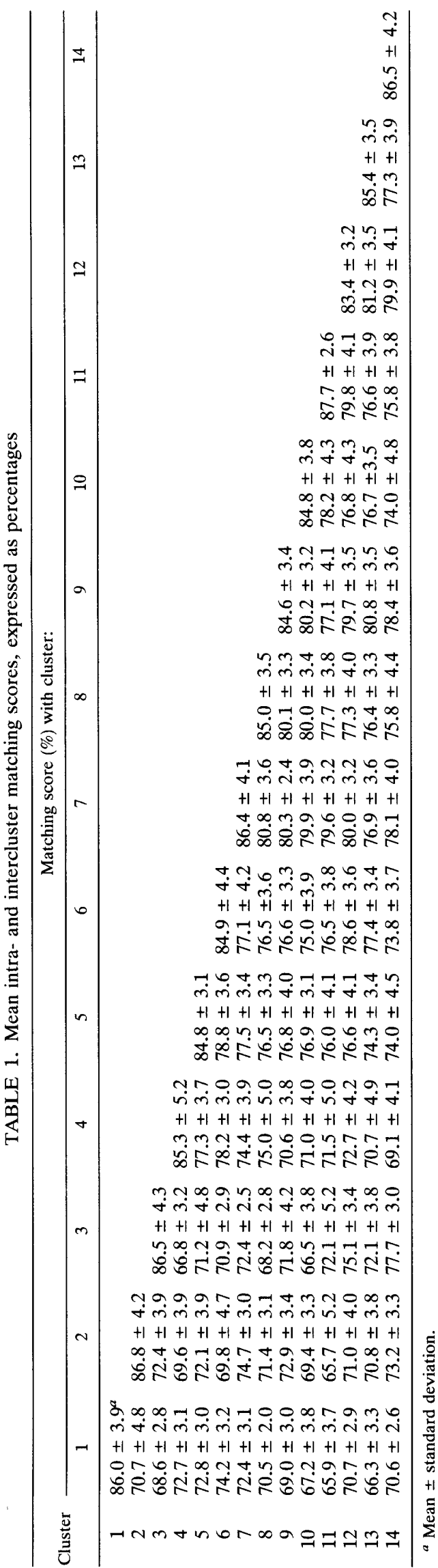

Systematic Bacteriology recently noted the impact on current bacterial taxonomy and nomenclature of techniques for measuring evolutionary divergence in the structure of semantides (i.e., large information-bearing molecules, such as nucleic acids and proteins) and offered recommendations for semantide-based criteria for defining new species (30). Semantide studies and NT are complementary disciplines; NT alone does not establish evolutionary relationships, but it helps to identify areas where molecular studies are needed to clarify or confirm such relationships (28). This is especially evident in attempts to interpret some of the results obtained in the present study. Two types of semantide analyses, deoxyribonucleic acid (DNA) hybridization and catalase immunological distance measurements, have clarified the status of several named mycobacterial species, providing evidence for confirming some species and reducing some species to synonymy with other species. The two methods show a high level of agreement in their power to distinguish between species that may not be easily resolved on the basis of NT alone. For example, T-catalase serology provided the same redistribution of $M$. avium complex serovars between $M$. avium and $M$. intracellulare as was dictated by DNA homology $(2,33)$, and the results of both DNA hybridization and catalase serology confirmed that $M$. scrofulaceum is a species distinct from either $M$. avium or $M$. intracellulare (1, 2,33 ). The ongoing IWGMT open-ended cooperative study is proving to be useful in mycobacterial systematics by (i) identifying previously unrecognized strain clusters and calling attention to the need for semantide analysis to establish their taxonomic status and (ii) providing information on frequency distributions of features that can be used for strain identification.

The earliest clusters to emerge in the NT matrix (Fig. 1), clusters 1 to 6 , are the most discrete ones, showing between 6 and $12.1 \% \Delta \mathrm{M}$ (percentage point difference between the mean intracluster matching score and the highest intercluster scores), with a mean value of $8.6 \%$ (calculated from data in Table 1). All of these clusters are comprised of strains that hydrolyze Tween 80 . M. szulgai (cluster 1) is a valid clinically significant species (22), members of which can readily be identified by conventional phenotypic examination (40). Its species status is supported by DNA hybridization (10) and M-catalase serology results (32). M. triviale (cluster 2) is a valid nomenspecies (22) that is usually joined with $M$. terrae and $M$. nonchromogenicum in a terrae complex for diagnostic purposes (40). DNA homology studies on the type strains support the resolution of this complex into the three phenotypically distinct named species (10).

$M$. shimoidei (cluster 3) was revived as a valid nomenspecies (24) after being omitted from the Approved Lists (22); since three of the cultures in cluster 3 were derived from the same patient, we studied only four strains of this species. However, these came from widely dispersed geographic regions, so more strains may emerge as laboratories become aware of this taxon. $M$. shimoide $i$ is phenotypically distinctive, but the available DNA data (10) are too limited to establish whether this species is closely related to any other species.

$M$. gordonae is a valid species (22), but cluster 4 is not highly representative because of the criteria for entry of strains into this study. M. asiaticum (cluster 5) is a valid nomenspecies (22) that is fairly well separated from its immediately neighboring clusters (Fig. 3), and both DNA hybridization and $\mathrm{M}$-catalase serology results support it as a phylogenetic species $(10,32)$. $M$. asiaticum has been implicated as the cause of human disease more frequently than $M$. 
TABLE 2. Mean matching scores of selected clusters with all marker strains, expressed as percentages

\begin{tabular}{|c|c|c|c|c|c|c|c|c|c|c|c|c|c|c|c|}
\hline \multirow{2}{*}{ Strain } & \multirow{2}{*}{ Species } & \multicolumn{14}{|c|}{ Mean matching score (\%) with cluster: } \\
\hline & & 1 & 2 & 3 & 4 & 5 & 6 & 7 & 8 & 9 & 10 & 11 & 12 & 13 & 14 \\
\hline OES 90117 & M. flavescens & 68.0 & 64.3 & 61.2 & 67.2 & 62.9 & 67.1 & 60.7 & 62.8 & 58.3 & 60.6 & 58.9 & 61.3 & 57.1 & 61.6 \\
\hline ES 90134 & M. szulgai & $84.9^{a}$ & 67.4 & 65.4 & 70.4 & 72.5 & 73.9 & 72.4 & 70.6 & 70.0 & 67.3 & 57.1 & 0.7 & 66.9 & 9.6 \\
\hline ES 90130 & M. kansasii & 79.6 & 67.5 & 65.8 & 70.1 & 70.0 & 71.0 & 65.4 & 65.9 & 62.8 & 61.0 & 62.2 & 8.7 & 64.2 & 70.0 \\
\hline OES 90137 & $M . x e n o p i$ & 71.3 & 65.0 & 71.7 & 64 & 63.7 & 67.7 & 65.1 & 65.0 & 67.5 & 61.2 & 68.5 & 9.2 & 66.5 & 70.7 \\
\hline OES 90136 & M. gastri & 68.4 & 64.7 & 66.7 & 65.6 & 64.9 & 65.7 & 64.9 & 63.4 & 59.9 & 58.0 & 63.9 & 6.9 & 60.0 & 69.2 \\
\hline OES 90119 & M. triviale & 71.3 & $83.6^{a}$ & 69.2 & 68.1 & 73.4 & 70.9 & 74.7 & 71.7 & 72.9 & 70.7 & 64.4 & 69.0 & 68.5 & 71.4 \\
\hline ES 90120 & $M$. terrae & 76.1 & 78.3 & 73.0 & 71.6 & 77.8 & 72.3 & 73.4 & 69.4 & 74.4 & 71.1 & 9 & 1.8 & 71.1 & 69.4 \\
\hline ES 90118 & nchromogenicum & 68.5 & 74.8 & 67.3 & 68.8 & 70.8 & 70.5 & 73.3 & 3 & 70.6 & 70.7 & 1 & 7.9 & 66.2 & 68.3 \\
\hline 013 & $M$. shimoidei & 69.4 & 73.3 & $86.9^{a}$ & 67.2 & 69.8 & 7 & 72.2 & 3 & O & & 6 & .1 & 70.4 & 77.6 \\
\hline ES 90133 & donae & 72.9 & 66.7 & 65.1 & $85.7^{a}$ & 77.2 & 77.7 & 71.3 & 73.7 & 69.6 & 69.2 & 68.7 & 8 & 70.2 & 67.9 \\
\hline 126 & $M$. & 71.9 & 69.5 & 66.1 & 75.0 & $83.5^{a}$ & 77.9 & 76.8 & 74.7 & 74.3 & 75.9 & 75.2 & 73.9 & 72.9 & 76.2 \\
\hline OES 90135 & M. intracellulare & 76.1 & 76.8 & 71.4 & 78.1 & 78.7 & 78.6 & $87.7^{a}$ & 80.1 & 78.4 & 79.5 & 79.5 & 78.1 & 74.5 & 76.3 \\
\hline 138 & M. avium & 68.5 & 72.4 & 73.1 & 72.6 & 76.1 & 74.6 & $85.4^{a}$ & 78.9 & 81.3 & 80.9 & 3.4 & 81.1 & 77.9 & 78.1 \\
\hline 132 & M. scroful & 69.7 & 69.0 & 65.3 & 72.6 & 72.6 & 75.5 & 78.9 & $86.7^{a}$ & 77.2 & 78.3 & 77.3 & 76.4 & 72.9 & 74.7 \\
\hline 39 & ffinicum"' & & 72 & 71. & 72 & 78.8 & 77.3 & 81 & 82.5 & $85.7^{a}$ & & 79.3 & 79.1 & 77.8 & 77.3 \\
\hline OES 90128 & M. s & & 68.7 & & 71 & 75 & 77.2 & 81 & 80 & 818 & $87.0^{a}$ & 80.2 & 78.7 & 79.5 & 74.7 \\
\hline OES 90125 & Imoense & 69.6 & 73.9 & 79.5 & 69. & 75.0 & 75.4 & 78.1 & 75.8 & 80.2 & 72.5 & 74.4 & 80.6 & 78.0 & $87.8^{a}$ \\
\hline OES 90129 & M. marinum & 68.6 & 72.5 & 67.0 & 74.9 & 75.2 & 73.4 & 74.2 & 73.6 & 70.7 & 73.6 & 69.2 & 74.1 & 71.2 & 70.0 \\
\hline
\end{tabular}

${ }^{a}$ Mean matching score of a type strain with the cluster in which it occurs.

gordonae (4), but the only useful and consistent distinguishing phenotypic feature among those used in most laboratories is that $M$. asiaticum is photochromogenic (Table 3), and $M$. gordonae is scotochromogenic (34). After the strain code was broken for the present analysis, one participating laboratory indicated that it could recognize strains of $M$. asiaticum by their TLC lipid patterns.

The unnamed cluster 6 presents taxonomic problems. Four of the cultures are from one patient in Japan (25) and thus probably represent a single strain. They appear in a very tight subcluster at the top of cluster 6 (Fig. 3). The next five cultures also appear as a homogeneous subcluster, and they were isolated from sputa from different patients in a laboratory in Japan over an 18-month period. We could not establish whether they represent repeated isolations of a single strain in the local environment. Before a decision can be made about naming this cluster, cultures should be subjected to semantide analyses, and additional strains should be sought in other laboratories.

Clusters 7 through 14 (Fig. 1) are much less clearly resolved from one another, with minimum $\Delta \mathrm{M}$ scores ranging from 2.2 to $7.9 \%$ (mean, $4.9 \%$ ) (calculated from data in Table 1). Clusters 7 through 11 comprise strains that do not hydrolyze Tween 80 and include taxa of the " $M$. avium complex" and the "MAIS intermediate" group $(9,38)$. The significance of the relative phenotypic similarities (Table 1) between pairs of clusters in this region of the NT matrix is difficult to assess. For example, cluster 11 shows a higher mean matching score with cluster $7(79.6 \%)$ than with the more immediately proximal clusters 10,9 , and $8(78.2,77.1$, and $77.8 \%$, respectively). Furthermore, the results obtained with nucleic acid probes confirmed the genotypic relatedness of selected strains in clusters 7 and 11. Similarly, cluster 9 has a higher mean matching score with cluster $13(80.8 \%)$ than with intervening clusters (clusters 10,11 , and $12 ; 80.2$, 77.1 , and $79.7 \%$, respectively). The apparent interposition of one or more clusters between two clusters that exhibit a higher mean intercluster matching score may be interpreted in terms of what we refer to as the Calder effect, after the artist Alexander Calder. Calder created mobile sculptures consisting of balanced arrays of objects suspended from horizontal supports, with each free to rotate around its vertical axis, thereby increasing or decreasing the horizontal distances between units or sets of suspended objects. An NT dendrogram may be considered analogous to a Calder mobile, with clusters free to rotate about the vertical axes, changing their relative horizontal distances from one another, but separated by fixed distances that correspond to the heights of the branching points, which reflect the matching scores. This mobility is reflected in the distributions of intercluster matching scores of $N \times N$ matrices as illustrated in Fig. 1 to 5 and Table 1.

The phenotypic similarity between strains of $M$. avium and strains of $M$. intracellulare has long been a source of disagreement about whether these organisms actually represented a single species (16). The confusion was compounded by assignment of members of agglutinating serovars 1,2 , and 3 to the species $M$. avium and 20 or more additional serovars to $M$. intracellulare. This was later simplified by assigning all agglutinating serovars of $M$. avium, $M$. intracellulare, and $M$. scrofulaceum to a single series of numbered serovars (43). Subsequently, Baess and colleagues demonstrated by DNA hybridization that $M$. avium, $M$. intracellulare, and $M$. scrofulaceum are phylogenetically distinct (1-3), but that several serovars formerly ascribed to $M$. intracellulare had to be reassigned to $M$. avium. These distinctions are also reflected in the serological divergence of the catalases (31, 33). Similarly, $M$. simiae (cluster 10 ), which met the criteria for the MAIS intermediate group (9), has been established as a distinct species by DNA homology $(3,10)$ and by catalase serology $(31,32)$.

In contrast, recent DNA studies have provided evidence that Mycobacterium paratuberculosis and Mycobacterium lepraemurium are synonymous with $M$. avium $(15,20,44)$. The phenotypic diversity and intercluster overlap seen in the organisms represented in the $M$. avium complex may be a consequence of both subspecific variations in the structure of their chromosomal DNAs, as reflected in the different restriction fragment length polymorphisms $(15,42)$ and the frequent presence of plasmids in members of this complex $(5,17)$. Since these factors also appear to be correlated with the association of strains with human disease, including acquired immunodeficiency syndrome and possibly Crohn's disease, and with Johne's disease in ruminants $(5,15,17)$, 
TABLE 3. Feature frequencies of 45 modal properties for 10 clusters of slowly growing mycobacteria

\begin{tabular}{|c|c|c|c|c|c|c|c|c|c|c|c|}
\hline \multirow{2}{*}{ Feature } & \multirow{2}{*}{$\begin{array}{l}\mathrm{RKC} \\
\text { no. }^{a}\end{array}$} & \multicolumn{10}{|c|}{ Frequency $(\%)$ in cluster: } \\
\hline & & 1 & 2 & 3 & 5 & 6 & 9 & 10 & 12 & 13 & 14 \\
\hline \multicolumn{12}{|l|}{ Growth in the presence of: } \\
\hline Oleate $(250 \mu \mathrm{g} / \mathrm{ml})$ & 16089 & 0 & 100 & & 60 & 50 & 100 & 100 & 75 & 67 & 0 \\
\hline Picrate $(2,000 \mu \mathrm{g} / \mathrm{ml})$ & 16259 & 0 & 0 & 0 & 0 & 0 & 0 & 16 & 0 & 0 & 0 \\
\hline Hydroxylamine $(125 \mu \mathrm{g} / \mathrm{ml})$ & 16261 & 86 & 100 & 100 & 100 & 70 & 86 & 100 & 88 & 92 & 100 \\
\hline Hydroxylamine $(500 \mu \mathrm{g} / \mathrm{ml})$ & 16263 & 0 & 100 & 0 & 82 & 10 & 71 & 100 & 31 & 25 & 63 \\
\hline $\mathrm{NaCl}(5 \%)$ & 18006 & 0 & 100 & 0 & 0 & 0 & 0 & 0 & 0 & 0 & 0 \\
\hline$p$-Nitrobenzoate $(500 \mu \mathrm{g} / \mathrm{ml})$ & 16264 & 100 & 100 & 100 & 100 & 100 & 100 & 100 & 100 & 100 & 100 \\
\hline Isoniazid $(1 \mu \mathrm{g} / \mathrm{ml})$ & 16250 & 40 & 100 & 100 & 91 & 100 & 100 & 100 & 88 & 100 & 100 \\
\hline Isoniazid $(10 \mu \mathrm{g} / \mathrm{ml})$ & 16251 & 0 & 100 & 0 & 10 & 0 & 83 & 75 & 0 & 40 & 0 \\
\hline Thiacetazone $(10 \mu \mathrm{g} / \mathrm{ml})$ & 16276 & 100 & 100 & 100 & 100 & 100 & 100 & 100 & 89 & 100 & 100 \\
\hline Thiophene-2-carboxylic hydrazide $(1 \mu \mathrm{g} / \mathrm{ml})$ & 16315 & 100 & 100 & 100 & 100 & 100 & 100 & 100 & 100 & 100 & 100 \\
\hline Ethambutol $(1 \mu \mathrm{g} / \mathrm{ml})$ & 16317 & 57 & & & 80 & 80 & 100 & 100 & 100 & 100 & 100 \\
\hline Ethambutol $(5 \mu \mathrm{g} / \mathrm{ml})$ & 16319 & 0 & 17 & 0 & 18 & 20 & 71 & 95 & 75 & 92 & 14 \\
\hline Ethambutol $(10 \mu \mathrm{g} / \mathrm{ml})$ & 98297 & 0 & 0 & 0 & 10 & 10 & 43 & 82 & 38. & 83 & 0 \\
\hline Capreomycin $(10 \mu \mathrm{g} / \mathrm{ml})^{b}$ & 40369 & 29 & 0 & 33 & 70 & 90 & 86 & 94 & 44 & 100 & 13 \\
\hline p-Aminosalicylate $(1 \mu \mathrm{g} / \mathrm{ml})$ & 16253 & & & 100 & & & & & & & 100 \\
\hline Ethionamide $(20 \mu \mathrm{g} / \mathrm{ml})$ & 16321 & 50 & 0 & 17 & 11 & 10 & 29 & 65 & 33 & 0 & 0 \\
\hline Cycloserine $(16 \mu \mathrm{g} / \mathrm{ml})$ & 98182 & 100 & 100 & 80 & 100 & 0 & 43 & 67 & 7 & 9 & 50 \\
\hline Toluidine blue $(300 \mu \mathrm{g} / \mathrm{ml})$ & 98032 & 67 & 100 & 100 & 100 & 78 & 57 & 100 & 86 & 75 & 63 \\
\hline Rifampin $(32 \mu \mathrm{g} / \mathrm{ml})$ & 40169 & 57 & 100 & 0 & 0 & 100 & 50 & 0 & 43 & 73 & 38 \\
\hline \multicolumn{12}{|l|}{ Growth characteristics } \\
\hline Growth at $22^{\circ} \mathrm{C}$ & 17036 & 100 & 100 & 0 & 100 & 100 & 100 & 100 & 94 & 100 & 88 \\
\hline Growth at $25^{\circ} \mathrm{C}$ & 17014 & 100 & 100 & & 100 & 100 & 100 & 100 & 100 & 100 & 100 \\
\hline Growth at $42^{\circ} \mathrm{C}$ & 17035 & 0 & 0 & 100 & 13 & & 0 & 9 & 13 & 9 & 0 \\
\hline Growth at $45^{\circ} \mathrm{C}$ & 17017 & 0 & 0 & 50 & 0 & 0 & 0 & 0 & 0 & 0 & 0 \\
\hline Photochromogenic & 20008 & 0 & 0 & 0 & 100 & 0 & 0 & 83 & 0 & 0 & 0 \\
\hline Scotochromogenic & 20087 & 100 & 0 & 0 & 0 & 0 & 71 & 0 & 31 & 100 & 0 \\
\hline Niacin accumulates & 24424 & 0 & 0 & 0 & 0 & 0 & 0 & 37 & 0 & 0 & \\
\hline \multicolumn{12}{|l|}{$\begin{array}{l}\text { Growth with the following compounds as sole } \mathrm{C} \\
\text { and/or } \mathrm{N} \text { sources: }\end{array}$} \\
\hline Glucose as $\mathrm{C}$ source & 25311 & 14 & 0 & 0 & 27 & 80 & 0 & 58 & 31 & 17 & \\
\hline 1-Propanol as C source & 26524 & 0 & & & & & & 89 & & & \\
\hline Glutamate as $\mathrm{C}$ and $\mathrm{N}$ sources & 29227 & 0 & 0 & 0 & 64 & 50 & 0 & 0 & 0 & 0 & \\
\hline Acetate as $\mathrm{C}$ source, glutamate as $\mathrm{N}$ source & 98091 & 86 & 50 & 17 & 91 & 100 & 86 & 100 & 100 & 100 & 13 \\
\hline Succinate as $\mathrm{C}$ source, glutamate as $\mathrm{N}$ source & 98092 & 0 & 0 & 0 & 73 & 70 & 0 & 53 & 31 & 17 & \\
\hline Pyruvate as $\mathrm{C}$ source, glutamate as $\mathrm{N}$ source & 98093 & 100 & 17 & 0 & 91 & 100 & 71 & 95 & 100 & 92 & 2 \\
\hline \multicolumn{12}{|l|}{ Enzymatic properties } \\
\hline Urease & 34143 & 86 & 0 & 0 & 0 & 0 & 0 & 95 & 31 & 8 & 50 \\
\hline Nicotinamidase & 30255 & 86 & & 100 & 0 & 100 & 60 & 65 & 100 & 70 & 100 \\
\hline Pyrazinamidase $\left(\mathrm{NH}_{3}\right.$ assay) & 30258 & 86 & 33 & 100 & 0 & 100 & 67 & 53 & 100 & 70 & 100 \\
\hline Pyrazinamidase (agar) & 98192 & 100 & 100 & & 40 & 100 & 71 & 90 & 100 & 83 & 71 \\
\hline$\alpha$-Esterase & 34146 & 84 & 0 & & 100 & 100 & 86 & 94 & 100 & 100 & 43 \\
\hline Acid phosphatase & 34136 & 100 & 100 & 100 & 100 & 86 & 0 & 0 & 7 & 0 & 0 \\
\hline$\beta$-Galactosidase & 34123 & 0 & 67 & 0 & 0 & 0 & 0 & 0 & 0 & 0 & \\
\hline Catalase produces $>45 \mathrm{~mm}$ of foam & 98009 & 100 & 100 & 0 & 100 & 90 & 71 & 89 & 20 & 60 & 3 \\
\hline Catalase resists $68^{\circ} \mathrm{C}$ & 24425 & 100 & 100 & 100 & 100 & 100 & 100 & 100 & 100 & 92 & 25 \\
\hline Nitrate reduction moderate & 98007 & 86 & 0 & 0 & 0 & 0 & 0 & 0 & 0 & 0 & 13 \\
\hline Tween hydrolysis (10 days) & 98030 & 57 & 67 & 100 & 100 & 78 & 0 & 0 & 87 & 70 & 100 \\
\hline Tween opacity ( 5 weeks) & 98037 & & 100 & 50 & 90 & 100 & 67 & 90 & 81 & 58 & 50 \\
\hline Aryl sulfatase ( 2 weeks) & 98002 & 10 & 83 & 0 & 67 & 100 & 0 & 44 & 14 & 9 & 43 \\
\hline
\end{tabular}

" RKC, Rogosa-Krichevsky-Colwell method for coding data on microbial strains for computers (18).

${ }^{b}$ The RKC system (18) codes for susceptibility to capreomycin; the computer output data were inverted for this table, in which levels of resistance are shown.

expanded studies on the molecular genetics of this group of organisms appear to be of high priority.

The status of cluster 9, which includes strain OES 90139, which was derived from the type strain of the former species "M. paraffinicum" (6), remains unclear. This species lost standing when it was omitted from the Approved Lists (22) because it could not be distinguished with confidence from $M$. scrofulaceum (34). Semantide-based comparisons are needed to determine whether " $M$. paraffinicum" should be revived as a species or whether the members of this poorly circumscribed cluster represent phenotypically atypical members of one or more different species.

Clusters 12 through 14 consist of strains that exhibit extensive overlap with one another and with clusters 7 through 11 (Fig. 1). M. malmoense (cluster 14) appears to represent a species that is distinct from other named species on the basis of catalase serology (32) and limited DNA hybridization studies (10). The relationship of clusters 12 and 13 to one another and to cluster 14 needs exploration by semantide-based techniques, especially since all three clusters include clinically significant strains.

\section{ACKNOWLEDGMENT}

This study was supported by the Medical Research Service of the Veterans Administration. 


\section{LITERATURE CITED}

1. Baess, I. 1979. Deoxyribonucleic acid relatedness among species of slowly growing mycobacteria. Acta Pathol. Microbiol. Immunol. Scand. Sect. B 87:221-226.

2. Baess, I. 1983. Deoxyribonucleic acid relationships between different serovars of Mycobacterium avium, Mycobacterium intracellulare, and Mycobacterium scrofulaceum. Acta Pathol. Microbiol. Immunol. Scand. Sect. B 91:201-203.

3. Baess, I., and M. Magnusson. 1982. Classification of Mycobacterium simiae by means of comparative reciprocal intradermal sensitin testing on guinea pigs and deoxyribonucleic acid hybridization. Acta Pathol. Microbiol. Immunol. Scand. Sect. B 90:101-107.

4. Blacklock, Z. M., D. J. Dawson, D. W. Kane, and D. McEvoy. 1983. Mycobacterium asiaticum as a potential pulmonary pathogen for humans. A clinical and bacteriologic review of five cases. Am. Rev. Respir. Dis. 127:241-244.

5. Crawford, J. T., and J. H. Bates. 1986. Analysis of plasmids in $M$. avium-intracellulare isolates from persons with acquired immunodeficiency syndrome. Am. Rev. Respir. Dis. 134:659661.

6. Davis, J. B., H. H. Chase, and R. L. Raymond. 1956. Mycobacterium paraffinicum $\mathrm{n}$. sp., a bacterium isolated from soil. Appl. Microbiol. 4:310-315.

7. Goodfellow, M., A. Lind, H. Mordarska, S. Pattyn, and M. Tsukamura. 1974. A co-operative numerical analysis of cultures considered to belong to the rhodochrous taxon. J. Gen. Microbiol. 85:291-302.

8. Gross, W. M., and L. G. Wayne. 1970. Nucleic acid homology in the genus Mycobacterium. J. Bacteriol. 104:630-634.

9. Hawkins, J. 1977. Scotochromogenic mycobacteria which appear intermediate between $M$. avium/intracellulare and $M$. scrofulaceum. Am. Rev. Respir. Dis. 116:963-964.

10. Imaeda, T., G. Broslawski, and S. Imaeda. 1988. Genomic relatedness among mycobacterial species by nonisotopic blot hybridization. Int. J. Syst. Bacteriol. 38:151-156.

11. Karasseva, V., J. Weiszfeiler, and E. Krasznay. 1965. Occurrence of atypical mycobacteria in Macacus rhesus. Acta Microbiol. Acad. Sci. Hung. 12:275-282.

12. Kubica, G. P., I. Baess, R. E. Gordon, P. A. Jenkins, J. B. G. Kwapinski, C. McDurmont, S. R. Pattyn, H. Saito, V. Silcox, J. L. Stanford, K. Takeya, and M. Tsukamura. 1972. A cooperative numerical analysis of rapidly growing mycobacteria. J. Gen. Microbiol. 73:55-70.

13. Kubica, G. P., V. A. Silcox, J. O. Kilburn, R. W. Smithwick, R. E. Beam, W. D. Jones, and K. D. Stottmeier. 1970. Differential identification of mycobacteria. VI. Mycobacterium triviale Kubica sp. nov. Int. J. Syst. Bacteriol. 20:161-174.

14. Marks, J., P. A. Jenkins, and M. Tsukamura. 1972. Mycobacterium szulgai-a new pathogen. Tubercle 53:210-214.

15. McFadden, J. J., P. D. Butcher, J. Thompson, R. Chiodini, and J. Hermon-Taylor. 1987. The use of DNA probes identifying restriction-fragment-length polymorphisms to examine the $M y$ cobacterium avium complex. Mol. Microbiol. 1:283-291.

16. Meissner, G., K. H. Schroder, G. E. Amadio, W. Anz, S. Chaparas, H. W. B. Engel, P. A. Jenkins, W. Käppler, H. H. Kleeberg, E. Kubala, M. Kubin, D. Lauterbach, A. Lind, M. Magnusson, Z. Mikova, S. R. Pattyn, W. B. Schaeffer, J. L. Stanford, M. Tsukamura, L. G. Wayne, I. Willers, and E. Wolinsky. 1974. A cooperative numerical analysis of nonscotoand nonphotochromogenic slowly growing mycobacteria. J. Gen. Microbiol. 83:207-235.

17. Meissner, P. S., and J. O. Falkinham. 1986. Plasmid DNA profiles as epidemiologic markers for clinical and environmental isolates of Mycobacterium avium, Mycobacterium intracellulare, and Mycobacterium scrofulaceum. J. Infect. Dis. 153: 325-331.

18. Rogosa, M., M. I. Krichevsky, and R. R. Colwell. 1971. Method for coding data on microbial strains for computers (edition AB). Int. J. Syst. Bacteriol. 21:1A-175A.

19. Saito, H., R. E. Gordon, I. Juhlin, W. Käppler, J. B. G. Kwapinski, C. McDurmont, S. R. Pattyn, E. H. Runyon, J. L. Stanford, S. Tarnok, H. Tasaka, M. Tsukamura, and J. W.
Weiszfeiler. 1977. Cooperative numerical analysis of rapidly growing mycobacteria. Int. J. Syst. Bacteriol. 27:75-85.

20. Saxegaard, F., and I. Baess. 1988. Relationship between Mycobacterium avium, Mycobacterium paratuberculosis and "wood pigeon mycobacteria". Acta Pathol. Microbiol. Immunol. Scand. Sect. B 96:37-42.

21. Schröder, K. H., and I. Juhlin. 1977. Mycobacterium malmoense sp. nov. Int. J. Syst. Bacteriol. 27:241-246.

22. Skerman, V. B. D., V. McGowan, and P. H. A. Sneath (ed.). 1980. Approved lists of bacterial names. Int. J. Syst. Bacteriol. 30:225-420.

23. Sneath, P. H. A., and R. R. Sokal. 1973. Numerical taxonomy. W.H. Freeman and Co., San Francisco.

24. Tsukamura, M. 1982. Mycobacterium shimoidei $\mathrm{sp}$. nov., nom. rev., a lung pathogen. Int. J. Syst. Bacteriol. 32:67-69.

25. Tsukamura, M., and H. Shimoide. 1977. Unusual strains of group III mycobacteria associated with pulmonary disease in a patient. Microbiol. Immunol. 21:473-474.

26. Walczak, C. A., and M. I. Krichevsky. 1980. Computer methods for describing groups from binary phenetic data: preliminary summary and editing of data. Int. J. Syst. Bacteriol. 30:615-621.

27. Walczak, C. A., and M. I. Krichevsky. 1980. Computer methods for describing groups from binary phenetic data: modification of numerical taxonomy programs to increase flexibility. Int. J. Syst. Bacteriol, 30:622-626.

28. Wayne, L. G. 1981. Numerical taxonomy and cooperative studies: roles and limits. Rev. Infect. Dis. 3:822-828.

29. Wayne, L. G., L. Andrade, S. Froman, W. Käppler, E. Kubala, G. Meissner, and M. Tsukamura. 1978. A co-operative numerical analysis of Mycobacterium gastri, Mycobacterium kansasii, and Mycobacterium marinum. J. Gen. Microbiol. 109:319-327.

30. Wayne, L. G., D. J. Brenner, R. R. Colwell, P. A. D. Grimont, O. Kandler, M. I. Krichevsky, L. H. Moore, W. E. C. Moore, R. G. E. Murray, E. Stackebrandt, M. P. Starr, and H. G. Trüper. 1987. Report of the Ad Hoc Committee on Reconciliation of Approaches to Bacterial Systematics. Int. J. Syst. Bacteriol. 37:463-464.

31. Wayne, L. G., and G. A. Diaz. 1982. Serological, taxonomic, and kinetic studies of the $T$ and $M$ classes of mycobacterial catalase. Int. J. Syst. Bacteriol. 32:296-304.

32. Wayne, L. G., and G. A. Diaz. 1985. Identification of mycobacteria by specific precipitation of catalase with absorbed sera. J. Clin. Microbiol. 21:721-725.

33. Wayne, L. G., and G. A. Diaz. 1986. Differentiation between T-catalases derived from Mycobacterium avium and Mycobacterium intracellulare by a solid-phase immunosorbent assay. Int. J. Syst. Bacteriol. 36:363-367.

34. Wayne, L. G., T. M. Dietz, C. Gernez-Rieux, P. A. Jenkins, W, Käppler, G. P. Kubica, J. B. G. Kwapinski, G. Meissner, S. R. Pattyn, E. H. Runyon, K. H. Schröder, V. A. Silcox, A. Tacquet, M. Tsukamura, and E. Wolinsky. 1971. A cooperative numerical taxonomic analysis of scotochromogenic slowly growing mycobacteria. J. Gen. Microbiol. 66:255-271.

35. Wayne, L. G., H. C. Engbaek, H. W. B. Engel, S. Froman, W. Gross, J. Hawkins, W. Käppler, A. G. Karlson, H. H. Kleeberg, I. Krasnow, G. P. Kubica, C. McDurmont, E. E. Nel, S. R. Pattyn, K. H. Schröder, S. Showalter, I. Tarnok, M. Tsukamura, B. Vergmann, and E. Wolinsky. 1974. Highly reproducible techniques for use in systematic bacteriology in the genus Mycobacterium: tests for pigment, urease, resistance to sodium chloride, hydrolysis of Tween 80 , and $\beta$-galactosidase. Int. J. Syst. Bacteriol. 24:412-419.

36. Wayne, L. G., H. W. B. Engel, C. Grassi, W. Gross, J. Hawkins, P. A. Jenkins, W. Käppler, H. H. Kleeberg, I. Krasnow, E. E. Nel, S. R. Pattyn, P. A. Richards, S. Showalter, M. Slosarek, I. Szabo, I. Tarnok, M. Tsukamura, B. Vergmann, and E. Wolinsky. 1976. Highly reproducible techniques for use in systematic bacteriology in the genus Mycobacterium. II. Tests for niacin and catalase and for resistance to isoniazid, thiophene 2-carboxylic acid hydrazide, hydroxylamine, and para-nitrobenzoate. Int. J. Syst. Bacteriol. 26:311-318.

37. Wayne, L. G., R. C. Good, M. I. Krichevsky, R. E. Beam, Z. Blacklock, S. D. Chaparas, D. Dawson, S. Froman, W. Gross, J. 
Hawkins, P. A. Jenkins, I. Juhlin, W. Käppler, H. H. Kleeberg, I. Krasnow, M. J. Lefford, E. Mankiewicz, C. McDurmont, G. Meissner, P. Morgan, E. E. Nel, S. R. Pattyn, F. Portaels, P. A. Richards, S. Rüsch, K. H. Schröder, V. A. Silcox, I. Szabo, M. Tsukamura, and B. Vergmann. 1981. First report of the cooperative, open-ended study of slowly growing mycobacteria by the International Working Group on Mycobacterial Taxonomy. Int. J. Syst. Bacteriol. 31:1-20.

38. Wayne, L. G., R. C. Good, M. I. Krichevsky, R. E. Beam, Z. Blacklock, H. L. David, D. Dawson, W. Gross, J. Hawkins, P. A. Jenkins, I. Juhlin, W. Käppler, H. H. Kleeberg, I. Krasnow, M. J. Lefford, E. Mankiewicz, C. MeDurmont, E. E. Nel, F. Portaels, P. A. Richards, S. Rüsch, K. H. Schröder, V. A. Silcox, I. Szabo, M. Tsukamura, L. Van den Breen, and B. Vergmann. 1983. Second report of the cooperative, open-ended study of slowly growing mycobacteria by the International Working Group on Mycobacterial Taxonomy. Int. J. Syst. Bacteriol. 33:265-274.

39. Wayne, L. G., E. J. Krichevsky, L. L. Love, R. Johnson, and M. I. Krichevsky. 1980. Taxonomic probability matrix for use with slowly growing mycobacteria. Int. J. Syst. Bacteriol. 30:528-538.

40. Wayne, L. G., M. I. Krichevsky, D. Portyrata, and C. K. Jackson. 1984. Diagnostic probability matrix for identification of slowly growing mycobacteria in clinical laboratories. J. Clin. Microbiol. 20:722-729.

41. Weiszfeiler, G., V. Karasseva, and E. Karczag. 1971. A new Mycobacterium species: Mycobacterium asiaticum $\mathrm{n}$. $\mathrm{sp}$. Acta Microbiol. Acad. Sci. Hung. 18:247-252.

42. Whipple, D. L., R. B. LeFebvre, R. E. Andrews, and A. B. Thiermann. 1987. Isolation and analysis of restriction endonuclease digestive patterns of chromosomal DNA from Mycobacterium paratuberculosis and from other Mycobacterium species. J. Clin. Microbiol. 25:1511-1515.

43. Wolinsky, E., and W. B. Schaefer. 1973. Proposed numbering scheme for mycobacterial serotypes by agglutination. Int. J. Syst. Bacteriol. 23:182-183.

44. Yoshimura, H. H., and D. Y. Graham. 1988. Nucleic acid hybridization studies of mycobactin-dependent mycobacteria. J. Clin. Microbiol. 26:1309-1312. 